Pak. j. sci. ind. res. Ser. A: phys. sci. 2021 64A(3) 254-264

\title{
Effect of Chemical Activating Agents on Surface Area and Methylene Blue Uptake Capacity of Activated Carbons
}

\author{
Muhammad Saleem \\ Civil Engineering Department, Jubail University College, Kingdom of Saudi Arabia
}

(received August 19, 2019; revised July 1, 2020; accepted July 6, 2020)

\begin{abstract}
Activated carbon from Acacia asak (Fabaceae) tree branches was prepared utilizing three-stepsprocess and $\mathrm{H}_{3} \mathrm{PO}_{4}, \mathrm{ZnCl}_{2}, \mathrm{H}_{2} \mathrm{SO}_{4}, \mathrm{~K}_{2} \mathrm{CO}_{3}, \mathrm{NaOH}$ and $\mathrm{KOH}$ as chemical activating agents. In addition to the elemental analysis of precursor materials, produced activated carbon (ATB-AC) was also analyzed for moisture content, ash content, $\mathrm{pH}$ value, bulk density, volatile matter, hardness, specific surface area $\left(\mathrm{S}_{\mathrm{BET}}\right)$, iodine number and pore volume. Results revealed that the quality of ATB-AC is well comparable to the available commercial activated carbon (CAC). The $\mathrm{S}_{\mathrm{BET}}$ was found to be in the order of ATB-AC1 $>$ ATBAC2 $>$ ATB-AC4 $>$ ATB-AC6 $>$ ATB-AC3 $>$ ATB-AC5. All the produced ATB-AC demonstrated good MB (methylene blue) removal efficiency, whereas ATB-AC1 and ATB-AC2 (produced from $\mathrm{H}_{3} \mathrm{PO}_{4}$, and $\mathrm{ZnCl}_{2}$ ) showed higher efficiency. It is concluded that the chemical activating agent has significant effect on produced AC keeping all other production parameters constant. Among the six studied chemicals, $\mathrm{H}_{3} \mathrm{PO}_{4}$ and $\mathrm{ZnCl}_{2}$ produced $\mathrm{AC}$ exhibited high $\mathrm{S}_{\mathrm{BET}}$ surface area and $\mathrm{MB}$ uptake capacity.
\end{abstract}

Keywords: activated carbon, activating agent, characterization, Acacia asak, $\mathrm{S}_{\mathrm{BET}}$ surface area, $\mathrm{MB}$ uptake capacity.

\section{Introduction}

Saudi Arabia has one of the largest industrial setup in the world including petroleum refineries and various units, manufacturing industrial and other commercial products (JC, 2016). These industries during production process generate huge amount of wastewater and require treatment before discharge to the environment or reuse. Growing concern on the increasing environmental pollution due to discharge of wastewater necessitates the treatment of wastewater up to the allowable limits for discharge or re-use (Danish and Ahmad, 2018). Various wastewater treatment processes have been developed to meet the strict pollution control legislations. Activated carbon (AC) is one of the robust tool to remove the pollutants from wastewater streams due to availability of high adsorbing surface area (Özsin et al., 2019). As reported in literature large quantity of $A C$ is being used in Saudi Arabia and most of it is imported to meet the requirements of AC. About 6.5 metric tonnes of AC was imported during 1995 to 2002 (Essa et al., 2004). The annual expenditure exceeds $\$ 3.2$ million for importing $\mathrm{AC}$ to meet the growing demand (Saleem et al., 2017).

Large surface area and physico-chemical properties of $\mathrm{AC}$ allows to preferentially adsorb organic materials and other polar and non polar compounds from gas or

*Author for correspondence; E-mail: SALEEM@ucj.edu.Sa liquid streams (Wang et al., 2012). Commercial AC are expensive, which limits the use of this excellent adsorbent (Lin and Wang, 2017). Stringent environmental legislations and environmental control policies demand huge quantities of $\mathrm{AC}$ having appropriate characteristics for each particular application. In order to solve this problem researchers utilized varieties of waste material to get economical $\mathrm{AC}$ possessing appropriate characteristics such as high BET surface area $\left(\mathrm{S}_{\mathrm{BET}}\right)$ and pollutant uptake capacity (Sartova et al., 2019). In general, an $\mathrm{AC}$ must have adequate adsorptive capacity, low ash content, mechanical strength and low production cost.

Preparation of activated carbon. Theoretically, AC can be produced by utilizing any material rich in carbonaceous material. Researchers tried varieties of material to get $\mathrm{AC}$ having high surface area and pollutant uptake capacity utilizing low cost precursor material (Ramirez et al., 2017).

Precursor materials utilized in the past. Literature shows that researchers utilized variety of materials including Moringa oleifera seeds (Warhurst et al., 1997), apricot (Erdoðan et al., 2005), corn cobs (Cao et al., 2006), date stones (Haimour and Emeish, 2006), cherry stones (Olivares-Marín et al., 2006), waste tea (Amarasinghe and Williams, 2007), cotton stalk (ElHendawy et al., 2008), olive stoves (Kula et al., 2008), olive cake (Baccar et al., 2009), bamboo (Liu et al., 
2010), almond shells (Plaza et al., 2010), giant seeds (Yue et al., 2010), coconut shell (Cazetta et al., 2011), Acacia mangium (Danish et al., 2013), date palm fronds (Ahmad et al., 2015), Acacia etbaica (Gebrekidan et al., 2015), olive stones (Yakout and El Deen, 2016), wood waste (Ramirez et al., 2017), waste tea (Zhou et al., 2018). More recently studies has been done on wine making wastes (Alcaraz et al., 2018), chickpea waste (Özsin et al., 2019), cotton processing wastes (Sartova et al., 2019), olive branches (Alkherraz et al., 2020), rice husks (Menya et al., 2020), Indonesian Mangrove (Budianto et al., 2019), etc. Reduction in the produced AC cost was the prime objective of most of the studies. The use of waste materials as low-cost adsorbents is a feasible option due to their contribution in reduction of waste disposal cost and pollution load on the environment (Sartova et al., 2019; Zhou et al., 2018; Ramirez et al., 2017). Production of AC required some physical and chemical activation treatment in addition to thermal treatment. Generally, AC production methods are proprietary and commercial in nature (Wong et al., 2018).

Production methods utilized in the past. Mohanty et al. (2005) produced AC by using Terminalia arjuna nuts as raw material in a $\mathrm{ZnCl}_{2}$ chemical activation method. When using a $300 \%\left(\mathrm{ZnCl}_{2} /\right.$ waste $)$ at $500^{\circ} \mathrm{C}$ carbonization temperature and a duration of $1 \mathrm{~h}$, the resulting $\mathrm{S}_{\mathrm{BET}}$ was $1260 \mathrm{~m}^{2} / \mathrm{g}$. Tsai et al. (2001) used corn cobs (as a carbonaceous material) and zinc chloride (as an activation agent) to produce activated carbon. The impregnation ratio, i.e., the $\mathrm{ZnCl}_{2} / \mathrm{cob}$ ratio and the activation temperature were noted as the most important factors. Ahmadpour et al. (1998) produced AC by using macadamia nutshell precursors along with $\mathrm{KOH}$ and $\mathrm{ZnCl}_{2}$ as the chemical activation agents. Qiao et al. (1997) report the use of pitch resulting from ethylene tar oil to produce activated carbon with high specific surface areas (approx. 2600 to $3600 \mathrm{~m}^{2} / \mathrm{g}$ ) that showed a significant adsorption tendency for benzene. Chemical activation was initiated by using $\mathrm{KOH}$.

Several other surface properties of the locally produced activated carbon samples were also studied and reported. Cox et al. (1999) produced activated carbon by employing flax shive as the raw material and $\mathrm{H}_{2} \mathrm{SO}_{4}$ as activating agent. The authors studied several variables such as the sulfuric acid solution strength and amount, temperature and time allowed for the reaction to proceed. Salame and Bandosz (2000) prepared activated carbon with wood. The activation agents were phosphoric acid and potassium hydroxide. The phosphoric acid activation produced activated carbon with a lower specific surface area compared with that from the potassium hydroxide activation (which produced activated carbon of upto $2300 \mathrm{~m}^{2} / \mathrm{g}$ specific surface area).

Lukman et al. (2013) reported the use of date palm tree branches for the production of $\mathrm{AC}$ with a high specific surface area and a high mesopore area. The optimum AC production conditions were found to be $\mathrm{H}_{3} \mathrm{PO}_{4}=$ $40 \%(\mathrm{w} / \mathrm{w})$ furnace hold temperature $(\mathrm{T})=700^{\circ} \mathrm{C}$, impregnation ratio $(\mathrm{R})=2(\mathrm{v}-\mathrm{acid} / \mathrm{w}-\mathrm{CB})$ and furnace hold time $(\mathrm{t})=1 \mathrm{~h}$. The AC sample that was produced by using the above mentioned chemical activation procedure and specific conditions exhibited an $\mathrm{S}_{\mathrm{BET}}$ (BET specific surface area) value of $1224 \mathrm{~m}^{2} / \mathrm{g}$, which was comparable to that of some widely used commercial AC samples. Additionally, the above mentioned AC sample also successfully removed $p$-cresol from a synthetic industrial wastewater sample. Furthermore, the activated carbon samples produced at 500 and $700^{\circ} \mathrm{C}$ showed good adsorption capacity.

Production of AC could be done by utilizing physical or chemical methods. Conveniently, AC can be produced in one or two steps. In a single step process carbonization and activation done simultaneously in a single step heating with an activation agent (Kalderis et al., 2008). In two step process first carbonization of precursor material performed in an inert atmosphere at a temperature range of $400^{\circ} \mathrm{C}$ to $800^{\circ} \mathrm{C}$ (Üner and Byrak, 2018; Chowdhury et al., 2013). In the second step activation of carbon done either by physical activation method utilizing steam, carbon dioxide or nitrogen (Alayan et al., 2019; Lua and Yang, 2005) or chemical activation processes utilizing an acid or a base (Herawan et al., 2013). Conventionally, activation temperature utilized is ranging from 800 to $1000^{\circ} \mathrm{C}$ (Guo and Lua, 2000).

Recently, it is reported that utilization of a three-stepsprocess produced high quality AC. Tran et al., (2017) prepared AC from Cassra fistula (Golden shower) in which hydrothermal carbonization process followed by pyrolysis process to form biochar. In the third step, obtained biochar was activated chemically utilizing potassium carbonate $\left(\mathrm{K}_{2} \mathrm{CO}_{3}\right)$ to produce $\mathrm{AC}$ having better adsorption performance for cationic dye than $\mathrm{AC}$ produced by single or two step processes (Tran et al., 2017). Studies shows that three-step synthesis is more effective approach for AC production (Wong et al., 2018). Studies reported in literature showing the AC produced by three-steps-process yield highest adsorption 
capacity which indicating importance of three-stepsprocess for production of good quality AC (AbdelKhalek et al., 2017; Singh et al., 2017). Therefore, in the present study a three-steps-process utilized to produce AC having high $\mathrm{S}_{\mathrm{BET}}$ surface area (Okman et al., 2014; Sun et al., 2010; Hayashi et al., 2000).

Rationale of utilizing chemical activation agents. In the chemical activation process, a carbonaceous material undergoes degradation and dehydration process with activating agents such as an acid or a base (Nor et al., 2013). Chemical activation generally done at low temperatures and shorter activation time than physical activation. (Nor et al., 2013; Guo and Lua, 2000). Therefore, process provides cost effective method for AC production by utilizing less energy and provide high $\mathrm{S}_{\mathrm{BET}}$ surface area and better yield (Herawan et al., 2013; Guo and Lua, 2000). Researchers utilized variety of activating agents, such as $\mathrm{H}_{3} \mathrm{PO}_{4}$ (Kalderis et al., 2008) $\mathrm{ZnCl}_{2}$ (Moreno-Pirajan and Giraldo, 2010), $\mathrm{KOH}$ (Romanos et al., 2011), $\mathrm{H}_{2} \mathrm{SO}_{4}$ (Jawad et al., 2016) and phytic acid, $\left(\mathrm{C}_{6} \mathrm{H}_{18} \mathrm{O}_{24} \mathrm{P}_{6}\right)$ (Cheng et al., 2016).

Although there were extensive researches in the past addressing the production and characterization of $\mathrm{AC}$ from various carbonaceous materials, yet there is limited information available about the use of Acacia asak tree branches (ATB) as a raw material. Production of activated carbon from ATB provides two fold benefits, acquiring a low cost $\mathrm{AC}$ from waste material generated during pruning of trees and reduction in the environmental pollution due to decay and disposal of this material (Shivayogimath et al., 2014).

Studies in the past revealed that AC was produced from different precursor materials and utilizing various activating agents. In addition to that, different production techniques and experimental conditions were utilized. Therefore, it is not possible to compare the performance of these ACs with each other and direct comparison of performance of such ACs in term of removal efficiency and adsorption capacity is meaningless. Present study is a step towards providing comparison between six different AC produced by three-steps-process utilizing six different activating agents and evaluate their properties to remove MB dye from wastewater effluent.

\section{Material and Methods}

Present study is aimed to utilize Acacia asak tree branches (ATB) to produce AC by three-steps-process. In order to compare the ability of six most commonly used chemical activating agents; $\mathrm{H}_{3} \mathrm{PO}_{4}, \mathrm{ZnCl}_{2}, \mathrm{H}_{2} \mathrm{SO}_{4}$, $\mathrm{K}_{2} \mathrm{CO}_{3}, \mathrm{NaOH}$ and $\mathrm{KOH}$ were used. Therefore, study is divided in three phases including (1) producing ATBAC utilizing three-steps-process, while using six above mentioned chemical activating agents. (2) characterizing the ATB-AC and (3) comparing the MB dye removal efficiency and adsorptive capacity of all ACs with the commercially available AC (Filtrasorb ${ }^{\circledR}-400$ ) available with Calgon Carbon Corporation.

Preparation of ATB-AC. Acacia asak tree branches collected from Jubal Industrial city. After washing with hot distilled water and drying, branches were cut into small pieces and dried in Blast Air Drying Oven (DHG9030A, China) at $110 \pm 5^{\circ} \mathrm{C}$ for $48 \mathrm{~h}$. Dried material was cut into 0.4 to $0.5 \mathrm{~mm}$ size particles utilizing variable speed Universal Cutting Mill (PULVERISETTE 19). Prepared granular material divided into six test samples and each sample passed through three-stepsprocess utilizing six activating agents $\mathrm{H}_{3} \mathrm{PO}_{4}, \mathrm{ZnCl}_{2}$, $\mathrm{H}_{2} \mathrm{SO}_{4}, \mathrm{~K}_{2} \mathrm{CO}_{3}, \mathrm{NaOH}$ and $\mathrm{KOH}$ to obtain ATB-AC1, ATB-AC2, ATB-AC3, ATB-AC4, ATB-AC5 and ATBAC6 respectively.

The prepared granular material was mixed with $50 \%$ $\mathrm{V} / \mathrm{V}$ distilled water and hydrothermal carbonization process applied to the material for $24 \mathrm{~h}$ at $200 \pm 5{ }^{\circ} \mathrm{C}$ in a sealed container. Steam produced in sealed container provide an extra pressure on the material and providing additional driving force for hydrochar production. Later produced hydrochar was mixed with $40 \% \mathrm{~V} / \mathrm{V}$ activating agent and slurry was left idle for $12 \mathrm{~h}$. In the last step, produced material was placed in Muffle Furness for 12 $\mathrm{h}$ at $600 \pm 5{ }^{\circ} \mathrm{C}$ to obtain final product. After that, the produce $\mathrm{AC}$ was cooled to room temperature and washed with $0.2 \% \mathrm{NaOH}$ solution (for ATB-AC1, ATB-AC2 and ATB-AC3) and $0.2 \% \mathrm{HCl}$ solution (for ATB-AC4, ATB-AC5 and ATB-AC6). Finally, produced AC is washed with distilled water to obtain $\mathrm{AC}$ having $\mathrm{pH}$ near neutral value.

In order to assess the properties of produced AC, characterization of produced $\mathrm{AC}$ was performed and discussed in the following section.

Characterization of ATB material and produced ACs. Characterization of produced ACs was done by following the standard procedures mentioned in the literature (Schaeffer, 2002). Bulk density was determined by standard ASTM D2395 method, moisture content by ASTM D4933-99, 201, fixed carbon by ASTM D3172; ISO 1350, volatile matter by ASTM D5832- 
98, hardness determined by Ball-Pan Hardness test using ASTM D3802 method, ash content by ASTM D2866-94, 2004, iodine number by ASTM D4607-94. The BET surface area $\left(\mathrm{S}_{\mathrm{BET}}\right)$ and pore volume were determined by utilizing the amount of $\mathrm{N} 2$ held at $\mathrm{P} / \mathrm{P}$ $=0.98$ reaching equilibrium. The $\mathrm{S}_{\mathrm{BET}}$ surface area determined by Quantachrome Nova-2200e series instrument. Pore mean radius $(\mathrm{R})$ is calculated from values of pore volume $(\mathrm{Vp})$ and $\mathrm{BET}$ surface area $\left(\mathrm{S}_{\mathrm{BET}}\right)$ utilizing the empirical relationship (Haul,1982).

$\mathrm{R}=2 \mathrm{Vp} / \mathrm{S}_{\mathrm{BET}}$

In order to determine the elemental composition of precursor material ATB, the PerkinElmer ${ }^{\circledR} 2400$ Series II CHNS/O Elemental Analyzer was used. The proximate analysis was performed by utilizing TGA 4000 System, with a compact ceramic furnace following the standard ASTM procedures. Hardness was determined by utilizing Gilson SS-30 Ro-Tap Sieve Shaker.

Efficiency of ATB-AC for methylene blue dye removal from industrial wastewater. Colouring dyes are the prime contaminant of wastewater generated in textile, paper, paints and plastics industries (Yaseen and Scholz, 2019). It is reported that textile industries using more than 3600 types of coloring dyes (pure earth and green cross Switzerland, 2017). A significant amount of such dyes are discharged into the water bodies (Wong et al., 2018; Ahmed et al., 2012). These dyes are not only harmful for aquatic animals such as fishes, also having negative effects on aquatic plants. Some of these dyes even comes under the priority pollutants list due to their mutagenicity and carcinogenicity (Kalita et al., 2017). Most of these dyes having very little removal during conventional wastewater treatments or even resistant against treatment (Regtiet et al., 2017). Methylene blue (MB) is one of the stuborn dye having severe to mild health effects including skin, eyes and brain related effects (Ardekani, 2017). Thus, large number of investigations for $\mathrm{MB}$ removal from industrial effluents are reported in the literature (Wong et al., 2018). In the present study synthetic wastewater containing MB dye used to test the produced ACs and determine their removal efficiency (Saleem et al., 2017; Shah et al., 2015).

Seven sets of $100 \mathrm{~mL}$ stopper flasks containing $10 \mathrm{~g}$ of ACs (produced six types of ACs and CAC, Filtrasorb ${ }^{\circledR}$ -400) were filled with $100 \mathrm{~mL}$ of solution having concentration of $50 \mathrm{mg} / \mathrm{L} \mathrm{MB}$ dye. Prepared flasks were placed in a speed adjustable orbital shaker (Model, NB10) at $300 \mathrm{rpm}$ and allowed to equilibrate for $48 \mathrm{~h}$ (Saleem et al., 2010). Later, $20 \mathrm{~mL}$ samples from each flask were filtered through $0.45 \mu \mathrm{m}$ filter (Millipore), and analyzed for residual concentrations of MB dye using the UV-spectrophotometer Shimadzu UV-1301PC at $644 \mathrm{~nm}$ wavelength. A calibration curve between absorbance and MB concentration was prepared by using MB standard solutions having concentrations from 10 to $60 \mathrm{mg} / \mathrm{L}$.

\section{Results and Discussion}

In the present experimental study six ACs were characterized and their properties were also compared. Results obtained in the present study are discussed in the following sections.

Production and characterization of AC. A comparison for the composition of ATB with other species of Acacia tree branches are presented in Table 2. It can be seen that all species of Acacia tree having higher carbon content along with lower ash content which is making ATB a candidate precursor material to obtain AC having qualities comparable to commercially available $\mathrm{AC}$ in market. As shown in Table 1 the composition of various elements are well comparable with the reported values in the literature for other acacia tree branches (Saleem et al., 2017; Shivayogimath et al., 2014). A precursor material having high carbon content and lower sulphur and ash results in better quality AC (Macías-Pérez et al., 2007). The Acacia asak also having low sulphur content $(0.02 \%)$ which may ranking it as an environment friendly precursor material to produce AC (Shahid et

Table 1. Results of elemental analysis and comparison with the other Acacia species reported in the literature.

\begin{tabular}{llll}
\hline \hline $\begin{array}{l}\text { Constituent } \\
(\%)\end{array}$ & $\begin{array}{l}\text { Acacia } \\
\text { asak }\end{array}$ & $\begin{array}{l}\text { Acacia } \\
\text { seyal }\end{array}$ & $\begin{array}{l}\text { Acacia } \\
\text { nilotica }\end{array}$ \\
\hline $\mathrm{C}$ & 52.7 & 51.3 & 48 \\
$\mathrm{~K}$ & 0.93 & 1.82 & -- \\
$\mathrm{Al}$ & $\mathrm{ND}$ & 0.17 & -- \\
$\mathrm{N}$ & 0.42 & 0.33 & 0.4 \\
$\mathrm{H}$ & 5.3 & 5.8 & 6 \\
$\mathrm{Zn}$ & 0.01 & 0.01 & -- \\
$\mathrm{S}$ & 0.02 & 0.03 & -- \\
$\mathrm{P}$ & 0.1 & 0.09 & -- \\
$\mathrm{O}$ & 41.5 & 32.9 & 44 \\
Ash & 4.7 & 5.9 & 5.8 \\
\hline \hline
\end{tabular}

ND: Not Detected; Saleem et al. (2017); Shivayogimath et al. (2014). 
al., 2011). Therefore, ATB could be use as an appropriate precursor material for good quality AC production.

A comparison of results obtained from proximate and detailed analysis for all six types of produced ACs along with a commercially available AC (Filtrasorb ${ }^{\circledR}-400$ ) presented in Table 2 . in which also shows comparison between produced six ACs with two other species of Acacia trees (Acacia seyal and Acacia nilotica) reported in the literature.

Results show that all ACs prepared in the present study by three-steps-process utilizing six chemical activating agents mentioned earlier, posses high $\mathrm{S}_{\mathrm{BET}}$ surface area, which is well comparable with the commercially available AC (Filtrasorb ${ }^{\circledR}-400$ ). Among six produced ACs, obtained $\mathrm{S}_{\mathrm{BET}}$ surface area is in the order of ATBAC1 $>$ ATB-AC2 $>$ ATB-AC4 $>$ ATB-AC6 $>$ ATB-AC3 $>$ ATB-AC5. Therefore, ATB-AC1 and ATB-AC2 achieved surface area more than CAC (1037 and 992 $\mathrm{m} 2 / \mathrm{g}$ respectively) as compared to other produced ACs. Similar trend in pore volume observed, which shows that AC produced from ATB using three-steps-process provides better carbonization and activation, which utilize $\mathrm{H}_{3} \mathrm{PO}_{4}$ and $\mathrm{ZnCl}_{2}$ as chemical activating agent. Similar results were reported elsewhere when comparing the AC produced by single, two and three steps chemical activation method (Tran et al., 2017). The three-steps- process provides higher surface area which may be attributed to the hydrothermal treatment of precursor material produced hydrochar which facilitate the better penetration of activating agent $\mathrm{H}_{3} \mathrm{PO}_{4}$ and $\mathrm{ZnCl}_{2}$ in the pore space, and results in relatively higher surface area during activation.

Results reported in Table 2 also showing that the obtained BET surface area of produced ACs are well comparable to the area obtained by researchers utilizing other species of Acacia tree branches; Acacia seyal and Acacia nilotica. Once comparing with the $\mathrm{S}_{\mathrm{BET}}$ surface area of Filtrasorb ${ }^{\circledR}-400$ (i.e $944 \mathrm{~m}^{2} / \mathrm{g}$ ) the surface areas of ATB-AC1 and ATB-AC2 are $9.85 \%$ and $5.1 \%$ higher than CAC respectively. Results of iodine number demonstrated similar behaviour.

Results of pore volume and iodine number showing that the properties of AC strongly depends on the type of preparation method and adsorbent pore volume depends on the type of activating agent utilized. Thus, three-steps-process seems to be more favorable method in the preparation of better $\mathrm{AC}$ and $\mathrm{H}_{3} \mathrm{PO}_{3}$, and $\mathrm{ZnCl}_{2}$ are most suitable chemical activating agents among six studied agents. A similar conclusion has been drawn by other researchers (Wong et al., 2018; Tran et al., 2017). The ball-pan hardness test which reflects the resistance of an $\mathrm{AC}$ against degradation, measured and

Table 2. Comparison of characteristics of six produced ACs with commercial ACs and AC produced from other species of Acacia tree

\begin{tabular}{|c|c|c|c|c|c|c|c|c|c|}
\hline Property & $\begin{array}{l}{ }^{*} \text { Filtrasorb } \mathbb{} \\
400\end{array}$ & ATB-AC1 & ATB-AC2 & ATB-AC3 & ATB-AC4 & ATB-AC5 & ATB-AC6 & $\begin{array}{l}\text { Acacia } \\
\text { seyal }\end{array}$ & $\begin{array}{l}\text { Acacia } \\
\text { nilotica }\end{array}$ \\
\hline $\begin{array}{l}\text { Activation } \\
\text { agent }\end{array}$ & -- & $\mathrm{H}_{3} \mathrm{PO}_{4}$ & $\mathrm{ZnCl}_{2}$ & $\mathrm{H}_{2} \mathrm{SO}_{4}$ & $\mathrm{~K}_{2} \mathrm{CO}_{3}$ & $\mathrm{NaOH}$ & $\mathrm{KOH}$ & $\mathrm{H}_{3} \mathrm{PO}_{4}$ & $\mathrm{KOH}$ \\
\hline $\begin{array}{l}\text { Ball-pan } \\
\text { hardness }\end{array}$ & High & 95 & 92 & 94 & 90 & 91 & 89 & 91 & Low \\
\hline Ash (\%) & $5-6$ & 3.21 & 6.13 & 5.74 & 5.73 & 6.25 & 6.78 & 5.9 & 5.8 \\
\hline $\begin{array}{l}\text { Bulk density } \\
(\mathrm{g} / \mathrm{cc})\end{array}$ & 0.44 & 0.51 & 0.47 & 0.49 & 0.35 & 0.39 & 0.41 & 0.3 & -- \\
\hline $\begin{array}{l}\text { Moisture } \\
\text { content }(\%)\end{array}$ & -- & 2.9 & 3.21 & 4.17 & 4.6 & 4.08 & 3.35 & 4.2 & 4.1 \\
\hline Volatile matter & -- & 2.42 & 3.16 & 2.79 & 2.73 & 3.24 & 2.78 & -- & 5.12 \\
\hline Fixed carbon & -- & 91.47 & 91.47 & 87.3 & 86.94 & 86.43 & 87.09 & -- & -- \\
\hline $\mathrm{pH}$ & 6.2 & 6.7 & 6.9 & 6.4 & 7.6 & 7.8 & 7.3 & 6.5 & 7.0 \\
\hline $\mathrm{S}_{\mathrm{BET}}\left(\mathrm{m}^{2} / \mathrm{g}\right)$ & 944 & 1037 & 992 & 792.6 & 814.3 & 781.6 & 805.5 & 762 & 590 \\
\hline $\begin{array}{l}\text { Pore volume } \\
\left(\mathrm{m}^{3} / \mathrm{g}\right)\end{array}$ & 0.7 & 5.26 & 5.07 & 4.82 & 5.1 & 4.76 & 4.91 & 4.92 & 4.4 \\
\hline $\begin{array}{l}\text { Pore mean } \\
\text { radius (mm) }\end{array}$ & 1.48 & 10.14 & 10.22 & 12.16 & 12.52 & 12.18 & 12.19 & 12.91 & 14.91 \\
\hline $\begin{array}{l}\text { Iodine number } \\
(\mathrm{mg} / \mathrm{g})\end{array}$ & 1000 & 927 & 895 & 879 & 892 & 867 & 886 & 827 & 480 \\
\hline
\end{tabular}

* Calgon carbon corporation, Pennsylvania, 15205 USA; (Saleem et al., 2017; Shivayogimath et al., 2014). 
results show that all the produced ACs possess very good hardness and well suitable for liquid phase batch and continues flow separation processes.

Furthermore, a basic cost analysis conducted while considering the procurement cost of precursor material, chemicals used, power consumed and labor cost. It was found that the final cost of produced ACs ranging from $\$ 0.4$ to $\$ 0.5$ per $\mathrm{Kg}$. Therefore, the AC produced by waste Acacia asak branches, which are available in abundance, obtained during tree pruning result in an economical means for producing $\mathrm{AC}$ as well as contribute in solid waste management and reduction.

Removal efficiency of ATB-ACs. Removal efficiency of ATB-ACs along with commercial AC Filtrasorb ${ }^{\circledR}$ 400 was evaluated in laboratory batch experiments in which produced and commercial ACs were suspended in $50 \mathrm{mg} / \mathrm{L} \mathrm{MB}$ solution as mentioned before.

The temporal removal efficiency of ATB-ACs and Filtrasorb ${ }^{\circledR}-400$ is depicted in Fig. 1. It is evident from Fig. 1. that initially commercial AC removal is highest up to $50 \mathrm{~min}$. as compared to all ATB-ACs however, after that, the removal efficiency of ATB-AC1 and ATB$\mathrm{AC} 2$ becomes comparable to it. After about $50 \mathrm{~min}$. of experimental run the improvement in the removal efficiency became insignificant for all the ACs. The final removal efficiencies of ACs achieved were 98.4\%,

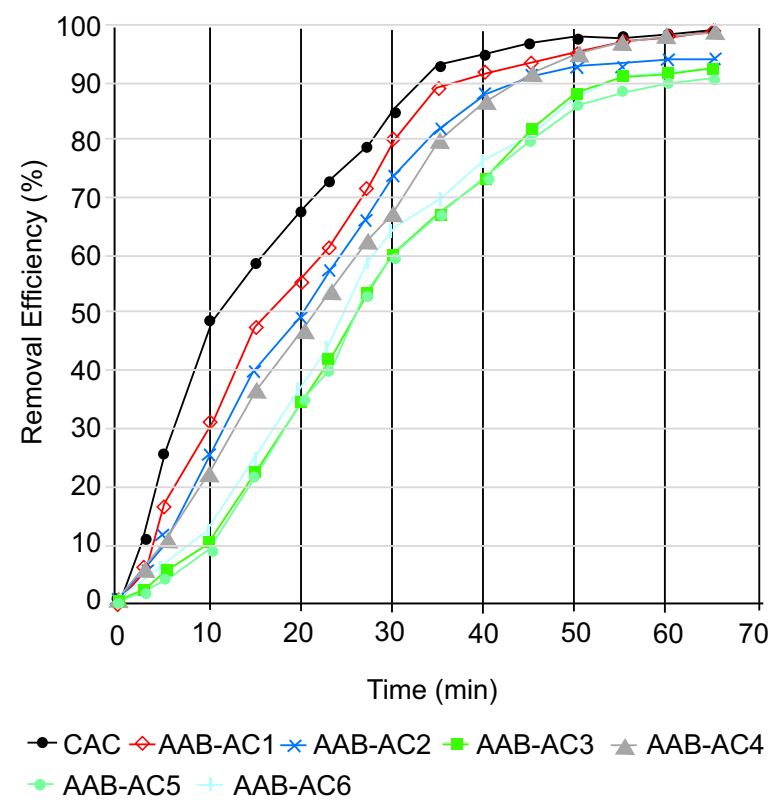

Fig. 1. Comparison of MB removal efficiency of produced ACs with CAC.
$98.8 \%, 98.3 \%, 92.4 \%, 94.3 \%, 90.7 \%$ and $92.8 \%$ for CAC, ATB-AC1, ATB-AC2, ATB-AC3, ATB-AC4, ATB-AC5 and ATB-AC6 respectively. The high removal efficiency of ATB-AC1 and ATB-AC2 for MB dye could be attributed to the utilization of $\mathrm{H}_{3} \mathrm{PO}_{4}$, and $\mathrm{ZnCl}_{2}$ as activating agent and three-steps-process which aids in the yield of high BET surface area and well developed porosity.

MB dye uptake capacity of ATB-AC. In this part of study the experimental runs were performed to compare the MB dye uptake capacity of all ATB-AC with commercial AC Filtrasorb ${ }^{\circledR}-400$. The uptake capacity of Filtrasorb ${ }^{\circledR}-400$ and ATB-AC are presented in Fig. 2. Results show that the adsorption capacity of ATBAC1, ATB-AC2, ATB-AC4 and ATB-AC6 (271.8, 264.9, 259.3, and $252.1 \mathrm{mg} \mathrm{MB} / \mathrm{g} \mathrm{AC}$ respectively) are higher than the CAC (235.3 mg MB/g AC). It can be seen that the pore volume of ATB-AC3 and ATB-AC5 is higher than the pore volume of $\mathrm{CAC}$ (4.82, 4.76 and $0.7 \mathrm{~m}^{3} / \mathrm{g}$ for ATB-AC3, ATB-AC5 and CAC respectively, as shown in Table 2), it means that the MB uptake capacity is not much depends on the pore volume and the controlling parameter could be the BET-Surface $\left(\mathrm{S}_{\mathrm{BET}}\right)$ area. Results reported here is in contrast with the conclusion of study reported by Hussein et al. (2015), which showing the dependency of AC uptake capacity solely on the pore structure and volume. Variance in the studies could be attributed to the use of different raw material (date palm tree biomass) which may

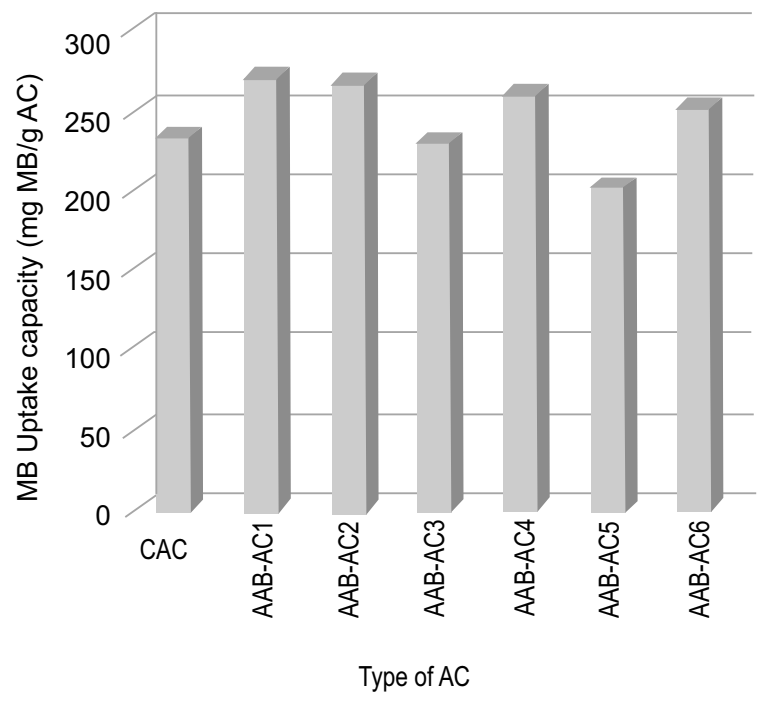

Fig. 2. Comparison of MB uptake capacity for ATB-ACs and CAC. 
produce pore volume due to different pore structure. However, further study is warranted to investigate effect of various precursor material on pore volume, $\mathrm{S}_{\mathrm{BET}}$ surface area and the uptake capacity.

Conclusions and Recommendations. Present study revealed that the Acacia asak tree branches available in Saudi Arabia as a waste material to dispose in cost effective and environment friendly way. Study show that ATB could be considered as an excellent raw material to produce valuable and good quality $\mathrm{AC}$ by three-steps-process utilizing chemical activating agents. Effects of various chemical activating agents evaluated by keeping all other production parameters constant and varing only the activating agents $\left(\mathrm{H}_{3} \mathrm{PO}_{4}, \mathrm{ZnCl}_{2}\right.$, $\mathrm{H}_{2} \mathrm{SO}_{4}, \mathrm{~K}_{2} \mathrm{CO}_{3}, \mathrm{NaOH}$ and $\mathrm{KOH}$ ) to provide a clear comparison. Following specific conclusions are drawn from the results of present study:

- Elemental analysis of precursor material revealed that the ATB having high carbon content (52.7\%), low sulphur and ash content $(0.02 \%$ and $4.7 \%$ respectively), thus ranking it as a suitable material for producing good quality and environment friendly AC.

- $\mathrm{H}_{3} \mathrm{PO}_{4}$ and $\mathrm{ZnCl}_{2}$ are better chemical agents as compared to $\mathrm{H}_{2} \mathrm{SO}_{4}, \mathrm{~K}_{2} \mathrm{CO}_{3}, \mathrm{NaOH}$ and $\mathrm{KOH}$ as produced $\mathrm{AC}$ possess high $\mathrm{S}_{\mathrm{BET}}$ surface area and pore volume ( $\mathrm{S}_{\mathrm{BET}}$ surface area 1037 and $992 \mathrm{~m}^{2} / \mathrm{g}$ respectively and pore volume 5.26 and $5.07 \mathrm{~m}^{3} / \mathrm{g}$ respectively) as compared to CAC (Filtrasorb ${ }^{\circledR}$ 400) having $\mathrm{S}_{\mathrm{BET}}$ area $944 \mathrm{~m}^{2} / \mathrm{g}$ and pore volume only $0.7 \mathrm{~m}^{3} / \mathrm{g}$.

- Temporal variation in removal efficiency of produced ACs with CAC investigated and found that the removal efficiency of CAC was high initially up to 30 min however, comparable removal efficiencies obtained after about 50 min of experimental runs ( $98.8 \%$ and $98.3 \%$ as compared to $98.4 \%$ for CAC).

- High hardness of produced ACs (Ball-pan hardness \# 89-95) suggests as suitable AC for batch-mixed as well as continues flow wastewater treatment systems.

- Produced ACs show high MB uptake capacity 235.3, $271.8,264.9,229.7,259.3,201.6$ and $252.1 \mathrm{mg}$ $\mathrm{MB} / \mathrm{g} \mathrm{AC}$ for CAC, ATB-AC1, ATB-AC2, ATB$\mathrm{AC} 3$, ATB-AC4, ATB-AC5 and ATB-AC6 respectively which may be attributed to high $\mathrm{S}_{\mathrm{BET}}$ surface area and pore volume produced during threesteps-process utilizing chemical activating agents.

- Among six produced ACs, ATB-AC1 and ATB-AC2 and ATB-AC6 demonstrated higher MB uptake capacity (produced by $\mathrm{H}_{3} \mathrm{PO}_{4}, \mathrm{ZnCl}_{2}$ and $\mathrm{KOH}$ respectively).

- Cost analysis for the production of AC shows that ATB can produce good quality AC and cost is between $\$ 0.4$ to $\$ 0.5 / \mathrm{Kg}$, which is making it economically feasible material as well.

Therefore, if considering the availability of low cost waste material and low energy consumption, in producing AC (by three-steps carbonization and activation method) ATB-AC could be a suitable candidate material for producing economical and well comparable AC (with commercially available ACs). Furthermore, research is warranted to test different chemical activating agents for their ability to produce $A C$ having high $S_{B E T}$ surface area and pore volume. In addition to that, further investigations are needed to evaluate other parameters including hydrolysis and activation time, temperature, impregnation ratio and other methods such as microwave heating.

\section{Acknowledgement}

Author is grateful to the JUC to provide environment to conduct this study and also thankful to KFUPM for providing technical support and advice and $\mathrm{Mr}$. Muhammad Taha Bin Saleem for providing help in editing and proof reading of manuscript.

\section{References}

Abdel-Khalek, M.A., Rahman, M.A., Francis, A.A. 2017. Exploring the adsorption behaviour of cationic and anionic dyes on industrial waste shells of egg. Journal of Environmental Chemical Engineering, 5: 319-327. https://doi.org/10.1016/j.jece.2016. 11.043

Ahmad, A., Al-Swaidan, H.M., Alghamdi, A.H. 2015. Production of activated carbon from raw Date palm fronds by $\mathrm{ZnCl}_{2}$ activation. Journal of the Chemical Society of Pakistan, 37: 1081-1087. https://jcsp.org. pk/issueDetail.aspx?aid=565422f7-3d5a-4ddf-8306d72b6f5a6349

Ahmadpour, A., King, B.A., Do, D.D. 1998. Comparison of equilibria and kinetics of high surface area activated carbon produced from different precursors and by different chemical treatments. Industrial \& Engineering Chemistry Research, 37: 1329-1334. https://doi.org/10.1021/ie970448h

Alayan, H.M., Alsaadi, M.A., AlOmar, M.K., Hashim, M.A. 2019. Growth and optimization of carbon nanotubes in powder activated carbon for an 
efficient removal of methylene blue from aqueous solution. Environmental Technology, 40: 24002415. https://doi.org/10.1080/09593330.2018. 1441911

Alcaraz, L., López-Fernández, A., García-Díaz, I., López, F.A. 2018. Preparation and characterization of activated carbons from wine making wastes and their adsorption of methylene blue. Adsorption Science \& Technology, 36: 1331-1351. https://doi. org/10.1177/0263617418770295

Alkherraz, A.M., Ali, A.K., Elsherif, K.M. 2020. Removal of $\mathrm{Pb}$ (II), $\mathrm{Zn}$ (II), $\mathrm{Cu}$ (II) and Cd (II) from aqueous solutions by adsorption onto olive branches activated carbon: equilibrium and thermodynamic studies. Chemistry International, 6: 11-20. https://doi.org/10.5281/zenodo.2579465

Amarasinghe, B.M.W.P.K., Williams, R.A. 2007. Tea waste as a low cost adsorbent for the removal of $\mathrm{Cu}$ and $\mathrm{Pb}$ from wastewater. Chemical Engineering Journal, 132: 299-309. https://doi.org/10.1016/j.cej. 2007.01.016

Ardekani, P.S., Karimi, H., Ghaedi, M., Asfaram, A., Purkait, M.K. 2017. Ultrasonic assisted removal of methylene blue on ultrasonically synthesized zinc hydroxide nanoparticles on activated carbon prepared from wood of cherry tree: experimental design methodology and artificial neural network. Journal of Molecular Liquids, 229: 114-124. https:// doi.org/10.1016/j.molliq.2016.12.028

Baccar, R., Bouzid, J., Feki, M., Montiel, A. 2009. Preparation of activated carbon from Tunisian olivewaste cakes and its application for adsorption of heavy metal ions. Journal of Hazardous Materials, 162: 1522-1529. https://doi.org/10.1016/j.jhazmat. 2008.06.041

Budianto, A., Kusdarini, E., Effendi, S.S.W., Aziz, M. 2019. The production of activated carbon from Indonesian Mangrove Charcoal. In: IOP Conference Series: Materials Science and Engineering, 462: 012006). IOP Publishing. https://iopscience.iop.org/ article/10.1088/1757-899X/462/1/012006/meta

Cao, Q., Xie, K.C., Lv, Y. K., Bao, W.R. 2006. Process effects on activated carbon with large specific surface area from corn cob. Bioresource Technology, 97: 110-115. https://doi.org/10.1016/j.biortech. 2005.02 .026

Cazetta, A.L., Vargas, A.M., Nogami, E.M., Kunita, M.H., Guilherme, M.R., Martins, A.C., Almeida, V. C. 2011. NaOH-activated carbon of high surface area produced from coconut shell: Kinetics and equilibrium studies from the methylene blue adsorption. Chemical Engineering Journal, 174: 117-125.

Cheng, C., Liu, H., Dai, P., Shen, X., Zhang, J., Zhao, T., Zhu, Z. 2016. Microwave-assisted preparation and characterization of mesoporous activated carbon from mushroom roots by phytic acid $\left(\mathrm{C}_{6} \mathrm{H}_{18} \mathrm{O}_{24} \mathrm{P}_{6}\right)$ activation. Journal of the Taiwan Institute of Chemical Engineers, 67: 532-537. https://doi.org/ 10.1016/j.cej.2011.08.058

Chowdhury, Z.Z., Hamid, S.B.A., Das, R., Hasan, R., Mohd, Z.S., Khalid, K., Uddin, N. 2013. Preparation of carbonaceous adsorbents from ligno cellulosic biomass and their use in removal contaminants from aqueous solution. Bio Resources, 8: 65236555. https://ojs.cnr.ncsu.edu/index.php/ BioRes/article/view/4292

Cox, M., EI-Shafey, E.I., Pichugin, A.A., Appleton, Q. 1999. Preparation and characterisation of a carbon adsorbent from flax shive by dehydration with sulfuric acid. Journal of Chemical Technology \& Biotechnology: International Research in Process, Environmental \& Clean Technology, 74: 10191029. https://doi.org/10.1002/(SICI)1097-4660 (199911)74:11<1019::AID-JCTB 152>3.0. $\mathrm{CO} ; 2-\mathrm{N}$

Danish, M., Ahmad, T. 2018. A review on utilization of wood biomass as a sustainable precursor for activated carbon production and application. Renewable and Sustainable Energy Reviews, 87: 1-21. https://doi.org/10.1016/j.rser.2018.02.003

Danish, M., Hashim, R., Ibrahim, M.M., Sulaiman, O. 2013. Effect of acidic activating agents on surface area and surface functional groups of activated carbons produced from Acacia mangium wood. Journal of Analytical and Applied Pyrolysis, 104: 418-425. https://doi.org/10.1016/j.jaap.2013.06.003

El-Hendawy, A.N.A., Alexander, A.J., Andrews, R.J., Forrest, G. 2008. Effects of activation schemes on porous, surface and thermal properties of activated carbons prepared from cotton stalks. Journal of Analytical and Applied Pyrolysis, 82: 272-278. https://doi.org/10.1016/j.jaap.2008.04.006

Erdogan, S., Önal, Y., Akmil-Basar, C., BilmezErdemoglu, S., Sarici-Özdemir, Ç., Köseoglu, E., Icduygu, G. 2005. Optimization of nickel adsorption from aqueous solution by using activated carbon prepared from waste apricot by chemical activation. Applied Surface Science, 252: 1324-1331. https:// doi.org/10.1016/j.apsusc.2005.02.089 
Essa, M.H., Al-Zahrani, M.A., Nesaratnam, S. 2004. A step towards national reliance using locally produced activated carbon from dates. In: Third Saudi Technical Conference and Exhibition (STCEX-3), Riyadh, Saudi Arabia. 291-297. https:// www.researchgate.net/profile/Muhammad_AlZahrani3/publication/268272667_A_Step_ Towards_National_Reliance_Using_Locally_Pro duced_Activated_Carbon_from_Dates/links/54b cd01c0cf24e50e9409416.pdf. Accessed on January, 2019. https://scholar.googleusercontent.com/ scholar?q=cache:oo7pt06jJbMJ:scholar.google.c om $/ \& h l=e n \& a s \_s d t=0,5$

Gebrekidan, A., Teferi, M., Asmelash, T., Gebrehiwet, K., Hadera, A., Amare, K., Van Der, B.B. 2015. Acacia etbaica as a potential low-cost adsorbent for removal of organochlorine pesticides from water. Journal of Water Resource and Protection, 7: 278. https://www.scirp.org/html/12-9402451_ 54284.htm

Guo, J., Lua, A.C. 2000. Effect of heating temperature on the properties of chars and activated carbons prepared from oil palm stones. Journal Thermal Analysis and Calorimetry, 60: 417-425. https://doi. org/10.1023/a:1010137308378

Haimour, N.M., Emeish, S. 2006. Utilization of date stones for production of activated carbon using phosphoric acid. Waste Management, 26: 651-660. https://doi.org/10.1016/j.wasman.2005.08.004

Haul, R., Gregg, S.J., Sing, K.S.W. 1982. Adsorption, surface area and porosity. Berichte der Bunsengesellschaft für Physikalische Chemie, 86: 1-957. https://doi.org/10.1002/bbpc. 19820861019

Hayashi, J.I., Kazehaya, A., Muroyama, K., Watkinson, A.P. 2000. Preparation of activated carbon from lignin by chemical activation. Carbon, 38: 1873878. https://doi.org/10.1016/S0008-223(00) 00027-0

Herawan, S.G., Hadi, M.S., Ayob, R., Putra, A. 2013. Characterization of activated carbons from oilpalm shell by $\mathrm{CO}_{2}$ activation with no holding carbonization temperature. Science World Journal, https://doi.org/10.1155/2013/624865

Hussein, F.H., Halbus, A.F., Lafta, A.J., Athab, Z.H. 2015. Preparation and characterization of activated carbon from Iraqi Khestawy date palm. Journal of Chemistry, 2015. http://dx.doi.org/10.1155/2015/ 295748. Accessed on July, 2016.

Jawad, A.H., Rashid, R.A., Ishak, M.A.M., Wilson, L.D. 2016. Adsorption of methylene blue onto activated carbon developed from biomass waste by $\mathrm{H}_{2} \mathrm{SO}$ activation: kinetic, equilibrium and thermodynamic studies. Desalination and Water Treatment, 57: 25194-25206. https://doi.org/10. 1080/19443994.2016.1144534

JC (Jeddah Chamber). Saudi Arabia - Industrial Sector Overview August 2016. Saudi Arabia - Industrial Sector Overview Report, 2016. Accessed on June $30^{\text {th }}, 2019$ (https://www.jeg.org.sa/sites/default/ files/library/files/Industry-EN.pdf).

Kalderis, D., Bethanis, S., Paraskeva, P., Diamadopoulos, E. 2008. Production of activated carbon from bagasse and rice husk by a single-stage chemical activation method at low retention times. Bioresource Technology, 99: 6809-6816. https://doi. org/10.1016/j.biortech.2008.01.041

Kalita, S., Pathak, M., Devi, G., Sarma, H. P., Bhattacharyya, K. G., Sarma, A., Devi, A. 2017. Utilization of Euryale ferox Salisbury seed shell for removal of basic fuchsin dye from water: equilibrium and kinetics investigation. RSC Advances, 7: 27248-27259. https://pubs.rsc.org/ lv/content/articlehtml/2017/ra/c7ra03014b

Kula, I., Ugurlu, M., Karaoglu, H., Celik, A. 2008. Adsorption of $\mathrm{Cd}$ (II) ions from aqueous solutions using activated carbon prepared from olive stone by $\mathrm{ZnCl}_{2}$ activation. Bioresource Technology, 99: 492-501. https://doi.org/10.1016/j.biortech.2007. 01.015

Lin, J.H., Wang, S.B. 2017. An effective route to transform scrap tire carbons into highly-pure activated carbons with a high adsorption capacity of ethylene blue through thermal and chemical treatments. Environmental Technology \& Innovation, 8: 17-27. https://doi.org/10.1016/j. eti.2017.03.004

Liu, Q.S., Zheng, T., Wang, P., Guo, L. 2010. Preparation and characterization of activated carbon from bamboo by microwave-induced phosphoric acid activation. Industrial Crops and Products, 31: 233238. https://doi.org/10.1016/j.indcrop.2009.10.011

Lua, A.C., Yang, T. 2005. Characteristics of activated carbon prepared from pistachio-nut shell by zinc chloride activation under nitrogen and vacuum conditions. Journal of Colloid and Interface Science, 290: 505-513. https://doi.org/10.1016/j.jcis.2005. 04.063

Lukman, S., Essa, M.H., Mu'azu, N.D., Bukhari, A. 2013. Coupled electro-kinetics-adsorption technique for simultaneous removal of heavy metals and organics from saline-sodic soil. The Scientific World 
Journal, 1-9. https://doi.org/10.1155/2013/346910

Macías-Pérez, M. C., Bueno-López, A., Lillo-Rodenas, M.A., de Lecea, C.S.M., Linares-Solano, A. 2007. $\mathrm{SO}_{2}$ retention on $\mathrm{CaO} /$ activated carbon sorbents. Part I: Importance of calcium loading and dispersion. Fuel, 86: 677-683. https://doi.org/10. 1016/j.fuel.2006.09.004

Menya, E., Olupot, P.W., Storz, H., Lubwama, M., Kiros, Y., John, M.J. 2020. Optimization of pyrolysis conditions for char production from rice husks and its characterization as a precursor for production of activated carbon. Biomass Conversion and Biorefinery, 10: 57-72. https://link.springer.com/ article/10.1007/s13399-019-00399-0

Mohanty, K., Jha, M., Meikap, B.C., Biswas, M.N. 2005. Removal of chromium (VI) from dilute aqueous solutions by activated carbon developed from Terminalia arjuna nuts activated with zinc chloride. Chemical Engineering Science, 60: 30493059. https://doi.org/10.1016/j.ces.2004.12.049

Nor, N.M., Lau, L.C., Lee, K.T., Mohamed, A.R. 2013. Synthesis of activated carbon from lignocellulosic biomass and its applications in air pollution control-a review. Journal of Environmental Chemical Engineering, 1: 658-666. https://doi.org/ 10.1016/j.jece.2013.09.017

Okman, I., Karagöz, S., Tay, T., Erdem, M. 2014. Activated carbons from grape seeds by chemical activation with potassium carbonate and potassium hydroxide. Applied Surface Science, 293: 138-142. https://doi.org/10.1016/j.apsusc.2013.12.117

Olivares-Marín, M., Fernández-González, C., MacíasGarcía, A., Gómez-Serrano, V. 2006. Preparation of activated carbons from cherry stones by activation with potassium hydroxide. Applied Surface Science, 252: 5980-5983. https://doi.org/10.1016/j.apsusc. 2005.11.018

Özsin, G., Kiliç, M., Apaydin-Varol, E., Pütün, A.E. 2019. Chemically activated carbon production from agricultural waste of chickpea and its application for heavy metal adsorption: equilibrium, kinetic, and thermodynamic studies. Applied Water Science, 9: 56. https://link.springer.com/article/10.1007/ s13201-019-0942-8

Plaza, M.G., García, S., Rubiera, F., Pis, J.J., Pevida, C. 2010. Post-combustion $\mathrm{CO}_{2}$ capture with a commercial activated carbon: comparison of different regeneration strategies. Chemical Engineering Journal, 163: 41-47. https://doi.org/10. 1016/j.cej.2010.07.030
Pure Earth and Green Cross Switzerland, 2017. The Toxins Beneath Our Feet. Accessed on August 2019.https://www.worstpolluted.org/.

Qiao, W., Ling, L., Zha, Q., Liu, L. 1997. Preparation of a pitch-based activated carbon with a high specific surface area. Journal of Materials Science, 32: 4447-4453. https://link.springer.com/article/10. 1023/A:1018600729419

Ramirez, A.P., Giraldo, S., Ulloa, M., Flórez, E., Acelas, N.Y. 2017. Production and characterization of activated carbon from wood wastes. Journal of Physics, 935, No. 1, p. 012012). IOP Publishing. https://iopscience.iop.org/article/10.1088/17426596/935/1/012012/meta

Regti, A., Laamari, M.R., Stiriba, S. E., El Haddad, M. 2017. Potential use of activated carbon derived from Persea species under alkaline conditions for removing cationic dye from wastewaters. Journal of the Association of Arab Universities for Basic and Applied Sciences, 24: 10-18. https://doi.org/10. 1016/j.jaubas.2017.01.003

Romanos, J., Beckner, M., Rash, T., Firlej, L., Kuchta, B., Yu, P., Suppes, G., Wexler, C. Pfeifer, P. 2011. Nanospace engineering of $\mathrm{KOH}$ activated carbon. Nanotechnology, 23: 015401. https://iopscience.iop. org/article/10.1088/0957-4484/23/1/015401/meta

Salame, I.I., Bandosz, T.J. 2000. Comparison of the surface features of two wood-based activated carbons. Industrial and Engineering Chemistry Research, 39: 301-306. https://doi.org/10.1021/ ie9906316

Saleem, M., Ali, M., Siddiqi, Z., Al Qahtani, A.S. 2017. Preparation of activated carbon from Acacia (Vachellia seyal) tree branches and application to treat wastewater containing methylene blue dye. Modern Applied Science, 11: pp. 102-108. DOI:10. 5539/mas.v11n12p102

Saleem, M., Mohsin, F., Zaman, N. 2010. Production, Characterization and Adsorption Isotherm Study for Activated Carbon Produced at KINPOE. $3^{\text {rd }}$ National "Energy Resources of Pakistan: Potential, Utilization, Conservation and Impact on Environment" at Quaid-e-Awam University of Engineering, Science \& Technology, Nawabshah, March 18-20, 2010. https://www.researchgate.net/ publication/303805558_Production_Characteriza tion_and_Adsorption_Isotherm_Study_for_Activ ated_Carbon_Produced_at_KINPOE

Sartova, K., Omurzak, E., Kambarova, G., Dzhumaev, I., Borkoev, B., Abdullaeva, Z. 2019. Activated 
carbon obtained from the cotton processing wastes. Diamond and Related Materials, 91: 90-97. DOI: 10.1016/j.diamond.2018.11.011

Schaeffer, K.E. 2002. ASTM International Activated Carbon Standards, stock Number ACTCARBON". ASTM Committee on Activated Carbon, D-28. 2002. DOI: 10.1520/D6851-02R11.

Shah, I., Adnan, R., Ngah, W.S.W., Mohamed, N. 2015. Iron impregnated activated carbon as an efficient adsorbent for the removal of methylene blue: regeneration and kinetics studies. PloS One, 10: e0122603. https://doi.org/10.1371/journal.pone. 0122603

Shahid, M., Saleem, M., Ibrahim, F. 2011. Production and characterization of activated carbon using indigenous waste materials. Pakistan Journal of Scientific \& Industrial Research, 54: 152-154. http://www.pjsir.org/documents/journals/211020 11055632_PJSIR54A(3)-Abstract.pdf. Accessed on January, 2017.

Shivayogimath, C.B., Hiremath, M.N., Lokeshappa, B. 2014. Preparation and characterization of granular activated carbon from Acacia nilotica stalk. International Journal of Engineering, Science and Innovative Technology, (IJESIT), 3: 201-207. http:// scholar.google.com/

Singh, H., Chauhan, G., Jain, A.K., Sharma, S.K. 2017. Adsorptive potential of agricultural wastes for removal of dyes from aqueous solutions. Journal of Environmental Chemical Engineering, 5: 122135. https://doi.org/10.1016/j.jece.2016.11.030

Sun, Y., Wei, J., Wang, Y.S., Yang, G., Zhang, J.P. 2010. Production of activated carbon by $\mathrm{K}_{2} \mathrm{CO}_{3}$ activation treatment of cornstalk lignin and its performance in removing phenol and subsequent bioregeneration. Environmental Technology, 31: 53-61. https://doi. org/10.1080/09593330903338411

Tran, H.N., You, S.J., Chao, H.P. 2017. Fast and efficient adsorption of methylene green 5 on activated carbon prepared from new chemical activation method. Journal of Environmental Management, 188: 322336. https://doi.org/10.1016/j.jenvman.2016.12.003

Tsai, W.T., Chang, C.Y., Wang, S.Y., Chang, C.F., Chien, S.F., Sun, H.F. 2001. Preparation of activated carbons from corn cob catalyzed by potassium salts and subsequent gasification with $\mathrm{CO}_{2}$. Bioresource Technology, 78: 203-208. https://doi.org/10.1016/
S0960-8524(00)00111-5

Üner, O., Bayrak, Y. 2018. The effect of carbonization temperature, carbonization time and impregnation ratio on the properties of activated carbon produced from arundo donax. Microporous and Mesoporous Materials, 268: 225-234. https://doi.org/10.1016/ j.micromeso.2018.04.037

Wang, H., Jahandar, L.M., Fayaz, M., Hashisho, Z., Philips, J.H., Anderson, J.E., Nichols, M. 2012. Adsorption and desorption of mixtures of organic vapours on beaded activated carbon. Environmental Science \& Technology, 46: 8341-8350. https://doi. org/10.1021/es3013062

Warhurst, A.M., McConnachie, G.L., Pollard, S.J. 1997. Characterisation and applications of activated carbon produced from Moringa oleifera seed husks by single-step steam pyrolysis. Water Research, 31: 759-766. https://doi.org/10.1016/S0043-1354 (97)80989-X

Wong, S., Ngadi, N., Inuwa, I.M., Hassan, O. 2018. Recent advances in applications of activated carbon from biowaste for wastewater treatment: a short review. Journal of Cleaner Production, 175: 361 375. https://doi.org/10.1016/j.jclepro.2017.12.059

Yakout, S. M., El-Deen, G. S. 2016. Characterization of activated carbon prepared by phosphoric acid activation of olive stones. Arabian Journal of Chemistry, 9: S1155-S1162. https://doi.org/10.1016/ j.arabjc.2011.12.002

Yaseen, D.A., Scholz, M. 2019. Textile dye wastewater characteristics and constituents of synthetic effluents: a critical review. International Journal of Environmental Science and Technology, 16: 1193-1226. https://link.springer.com/article/10. 1007/s13762-018-2130-z

Yue, Q.Y., Wang, W.Y., Gao, B. Y., Xu, X., Zhang, J., Li, Q. 2010. Phosphate removal from aqueous solution by adsorption on modified giant reed. Water Environment Research, 82: 374-381. https:// doi.org/10.2175/106143009X12529484815719

Zhou, J., Luo, A., Zhao, Y. 2018. Preparation and characterisation of activated carbon from waste tea by physical activation using steam. Journal of the Air \& Waste Management Association, 68: 12691277. https://doi.org/10.1080/10962247.2018. 1460282 